\title{
Corrosion resistance of fly ash-based geopolymer in hydrochloric and sulfuric acid solutions
}

\author{
(Resistência à corrosão de geopolímero à base de cinza \\ volante em soluções de ácido clorídrico e sulfúrico)
}

\author{
L.F.T.Domingos ${ }^{1 *}$,A.G.S.Azevedo ${ }^{1}$, C.T. Lombardi ${ }^{2}$, K. Strecker ${ }^{2}$ \\ ${ }^{1}$ Federal University of São João del-Rei, Department of Natural Sciences, 36301-160, São João Del Rei, MG, Brazil \\ ${ }^{2}$ Federal University of São João del-Rei, Department of Mechanical Engineering, São João del-Rei, MG, Brazil
}

\begin{abstract}
Currently, there is a growing interest in the use of industrial waste as a raw material in obtaining and developing new products in order to meet technological and environmental demands. Fly ash, for example, when in contact with an alkaline medium, forms inorganic polymers or geopolymers, which have properties comparable to ordinary Portland cement (OPC), but are capable of reducing up to $95 \%$ of $\mathrm{CO}_{2}$ emission into the atmosphere. In this study, the corrosion resistance of a geopolymer produced by the alkaline activation of fly ash type $\mathrm{F}$ was evaluated in $3 \%, 6 \%$, and $9 \%$ hydrochloric and sulfuric acid solutions for up to 28 days. The materials showed an average loss in terms of compressive strength of approximately $29,8 \%$ and $39,5 \%$ after 28 days of immersion in $\mathrm{HCl}$ and $\mathrm{H}_{2} \mathrm{SO}_{4}$, respectively. The immersion in $\mathrm{HCl}$ showed divergent results due to the formation of $\mathrm{NaCl}$ crystals around the microstructure of the material.
\end{abstract}

Keywords: fly ash, geopolymer, corrosion resistance.

\section{Resumo}

Atualmente existe um interesse crescente no uso de resíduo industrial como matéria-prima na obtenção e desenvolvimento de novos produtos, a fim de atender as demandas tecnológicas e ambientais. As cinzas volantes, por exemplo, quando em contato com um meio alcalino formam polímeros inorgânicos ou geopolímeros, que possuem propriedades comparáveis com às do cimento Portland comum, mas são capazes de reduzir até $95 \%$ de emissão de $\mathrm{CO}_{2}$ na atmosfera. Neste trabalho, a resistência à corrosão de um geopolímero produzidos pela ativação alcalina de cinza volante tipo $F$ foi avaliada em soluções de 3\%, 6\% e 9\% de ácidos clorídrico e sulfúrico por até 28 dias. Os materiais apresentaram perda média total em termos de resistência à compressão de aproximadamente 29,8\% e 39,5\% após 28 dias de imersão em $\mathrm{HCl}$ e $\mathrm{H}_{2} \mathrm{SO}_{4}$, respectivamente. A imersão em $\mathrm{HCl}$ apresentou resultados divergentes devido à formação de cristais de $\mathrm{NaCl}$ em torno da microestrutura do material.

Palavras-chave: cinza volante, geopolímero, resistência à corrosão .

\section{INTRODUCTION}

Ordinary Portland cement (OPC) is the most commonly used binding material in the construction industry. However, during its synthesis, large amounts of $\mathrm{CO}_{2}$ are released (1 ton of cement produced generates approximately 1 ton of $\mathrm{CO}_{2}$ ), contributing to the greenhouse effect $[1,2]$. Considering the problems concerning the environment, the search for new types of binders, capable of replacing Portland cement, is necessary. These materials must be capable of replacing traditional cement, guaranteeing high mechanical resistance, chemical inertia, a gain of mechanical resistance in short periods of cure, resistance to acid and sulfate attacks, besides presenting low-cost [35]. Alkali-activated inorganic polymers or geopolymers

*luistonholo@gmail.com

Dhttps://orcid.org/0000-0003-2605-1220 are potential substitutions of Portland cement in the most diverse areas of civil construction. This new class of materials was first described by Glukhovsky in 1959, the year in which the fundamental theory of alkaline activation developed [6]. In the mid-1970s, the expression geopolymer was first created by Joseph Davidovits when he designated the term geopolymerization as the process of synthesis of these materials [7]. The structure of geopolymers consists of $\mathrm{SiO}_{4}$ and $\mathrm{AlO}_{4}$, tetrahedrally linked by shared oxygens in the form of poly(sialates), poly(sialate-siloxo), or poly(sialatedisiloxo) depending on the $\mathrm{SiO}_{2} / \mathrm{Al}_{2} \mathrm{O}_{3}$ ratio in the system. Alkali ions balance the charge associated with tetrahedral Al. Conventionally, geopolymers are synthesized from a two-part mix, consisting of an alkaline solution and solid aluminosilicate materials, such as metakaolin or fly ash.

Due to the important aspects and incentives for the production of alkali-activated materials when compared to Portland cement, it is important to highlight their behavior when inserted in environments that present different 
chemical characteristics such as acidic, basic, or brackish. Among the many materials studied to be used even as an anticorrosive coating, the geopolymers, which present good characteristics of hardness, resistance in corrosive environments, and thermal stability, have become a great alternative to overcome any other type of cement-based compound. One study [8] evaluated the behavior of the geopolymers exposed to 1,2 , and $4 \mathrm{M}$ acid solutions for a different time. The authors report that resistance to acidic attacks of geopolymers is superior when compared to Portland cement. It was also observed that, in the first 4 weeks, the compressive strength decreased slightly by $4 \%$. However, this trend changed when the exposure time changed from 4 to 8 weeks, when the compressive strength increased by $3 \%, 0.5 \%$, and $1 \%$ for solutions of 4,2 , and 1 $\mathrm{M}$ hydrochloric acid, respectively, a fact which was related to the formation of a layer on the surface [8]. In another study about corrosion tests of geopolymeric structures [9], the author sought to understand the durability of the geopolymers made with fly ash with different types of alkaline solutions $\left(\mathrm{NaOH}\right.$ and $\left.\mathrm{Na}_{2} \mathrm{SiO}_{3}\right)$, which were immersed in 5\% acetic acid solutions $(\mathrm{pH}=2.4)$ and sulfuric acid $(\mathrm{pH}=0.8)$ for 5 months. The geopolymers produced from the $\mathrm{NaOH}$ activation obtained better responses in terms of stability and strength in the respective media that were submitted. For the author, in acid environments, high-performance geopolymer materials deteriorate through the formation of fissures in the amorphous polymer matrix. Aiming for a better comparison, the same tests using Portland cement was performed, where it was observed that, just after the first month of the corrosion process, the material deteriorated almost completely, a fact that is related to the high content of calcium present in this type of material [9]. Considering the important behavior exhibited by geopolymer materials when exposed in corrosive environments, it is also possible to find some studies $[10,11]$ that realized a comparative study of geopolymers prepared in high and low calcium concentration by immersing them in alkaline solution $(\mathrm{NaOH} 14 \mathrm{~mol} / \mathrm{L})$ in order to analyze the corrosion process and possible structural changes of the material. It was observed that the calcination of the geopolymers and their mineralogical composition are preponderant factors, which resulted in a reduction of $30 \%$ in the compressive strength [10], that is, the higher the amount of calcium present in the raw material (fly ash), the lower the final strength [11].

Thus, the objective of this study was the investigation of the structural-mechanical behavior of the geopolymeric structures produced from the alkali activation of fly ash when immersed in solutions of hydrochloric acid $(\mathrm{HCl})$ and sulfuric acid $\left(\mathrm{H}_{2} \mathrm{SO}_{4}\right)$ with concentrations of $3 \%, 6 \%$, and $9 \%$ and immersion periods ranging up to 28 days. The choice of these acids was related to their presence on a large scale in several sectors, such as mining, food industries, sewage pipes, etc. The importance of understanding how these materials behave in an acid environment is necessary to apply this new class of materials in industrial sectors without deterioration of its physical and mechanical integrity.

\section{MATERIALS AND METHODS}

Materials. Fly ash: the fly ash used in this study is an industrial residue produced in the thermoelectric power generation complex Jorge Lacerda located in the city of Capivari de Baixo in the State of Santa Catarina, Brazil, which is commercialized by the Pozo Fly Co. Fly ash is classified as being fine residues from the burning of coal in thermoelectric plants [12]. Ashes from the combustion of this coal are carried by the gases released in the combustion and later collected in electrostatic precipitators installed in the chimneys of the thermoelectric stations. The ashes are received in raw form and undergo storage, grinding, and bagging processes, for later distribution by the company itself. Alkaline activator and acid solutions: for the preparation of the alkaline solutions, sodium hydroxide with a purity of $98 \%$ was used in the form of flakes (Sulfal Química). Sulfuric and hydrochloric acids (Sigma-Aldrich) with a purity of $99 \%$ were used to prepare the diluted acid solutions for the corrosion tests.

Methods. Activator solution: the alkaline activator solution was prepared by dissolving $\mathrm{NaOH}$ in deionized water to obtain a final concentration of $16 \mathrm{~mol} / \mathrm{L}$. The preparation of this solution was conducted meticulously because of the highly exothermic nature of $\mathrm{NaOH}$ dissolution; the solution was then allowed to cool to room temperature for $24 \mathrm{~h}$ prior to its use. Alkaline activation of the fly ash: the polymerization process of fly ash by the alkaline activator solution was carried out by homogenizing the sieved fly ash (100 mesh) in a mechanical mixer with the $16 \mathrm{~mol} / \mathrm{L} \mathrm{NaOH}$ solution for $3 \mathrm{~min}$. The paste was poured into cylindrical plastic molds of $50 \mathrm{~mm}$ in height and $25 \mathrm{~mm}$ in diameter, and subsequently vibrated on a vibrating table for approximately $2 \mathrm{~min}$, ensuring better accommodation of the paste inside the molds and removal of air bubbles [13]. The molds were then sealed with plastic film to prevent loss of water by evaporation. After $24 \mathrm{~h}$, the film was removed, and the samples were cured in an oven at $90{ }^{\circ} \mathrm{C}$ for $24 \mathrm{~h}$. The hardened geopolymer specimens were subsequently demolded and further cured at room temperature for 1, 3, 7, 14 , and 28 days.

Corrosion testing of geopolymer specimens: the corrosion tests were conducted following the parameters described in [14], by the immersion of geopolymer specimens in $\mathrm{HCl}$ and $\mathrm{H}_{2} \mathrm{SO}_{4}$ acid solutions of concentrations of $3 \%, 6 \%$, and $9 \%$ for 1, 3, 7, 14, and 28 days. Mechanism of reaction involved in the corrosion process: the reaction mechanism present in a corrosion process involves two stages: 1) the first step corresponds to the process of leaching, the process of extracting a solid medium through its dissolution in a liquid medium. Initially, analyzing the Eq. A, it is possible to verify that in the geopolymeric structure I, composed of Al-O-Si networks, the aluminum atom is making 4 bonds, making it tetrahedral. This coordination is unfeasible because it only presents $3 \mathrm{e}^{-}$in its electron cloud (family $3 \mathrm{~A}$ ). In addition, a negative charge is formed when the $\mathrm{Al}$ atoms form tetrahedra with the oxygen atoms, requiring a positive 
charge for the electroneutrality to be obtained. This positive charge comes from the alkali cation $\left(\mathrm{Na}^{+}\right)$from the activating solution $(\mathrm{NaOH} 16 \mathrm{~mol} / \mathrm{L})$. Subsequently, when structure $\mathrm{I}$ is submerged in an acidic solution, the aluminum and sodium atoms are replaced by $\mathrm{H}^{+}$or $\mathrm{H}_{3} \mathrm{O}^{+}$ protons. This is due to the electrophilic attack of these acid protons (II) on the Si-O-Al bonding framework, thus resulting in the ejection of the aluminum from its geopolymeric ordination. However, from this ejection, the geopolymeric structure is undone, and a vacant structure is formed (III).

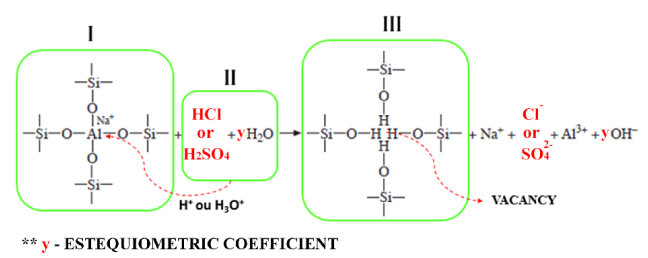

2) In the $2^{\text {nd }}$ step (Eq. B), the vacant structure formed in Eq. A is re-occupied by silicon atoms derived from $\mathrm{Si}(\mathrm{OH})_{4}$, silanol groups (IV). After this polycondensation process, a structure of octahedral and highly siliceous geometry is formed (V). However, it is important to point out that it is not a geopolymeric structure that returns to its original state, since once the aluminum and sodium atoms are removed from the initial composition (I) due to the acid attack, the mechanical characteristics, for example, decay significantly, causing this material to definitively lose the characteristics of an aluminosilicate.

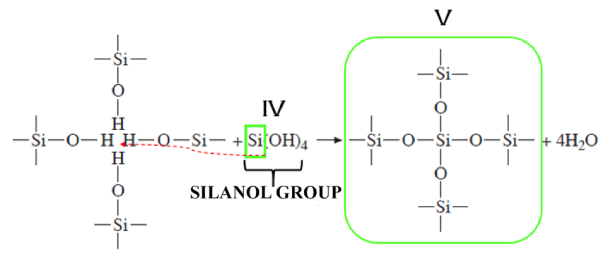

Characterizations: the chemical composition of the fly ash used was determined using an energy dispersive X-ray fluorescence spectrometer (XRF, EDX 8000, Shimadzu). The classification of the fly ash was done based on the BS EN ISO 10545-3:1997 standard. For the analysis of crystalline phases present in the precursor material, X-ray diffraction (XRD) analysis was done with a diffractometer (XRD-6000, Shimadzu) using a voltage of $30 \mathrm{kV}$, current of $30 \mathrm{~mA}, \mathrm{CuK} \alpha$ radiation $(\lambda=0.15462 \mathrm{~nm})$, a step width of $0.02^{\circ}$, and a scan speed of $2^{\circ} / \mathrm{min}$, between $5^{\circ}$ and $65^{\circ}$. After submitting samples to the corrosion process in the respective acid solutions of different concentrations and immersion times, their strength was determined by uniaxial compression test in compliance to ABNT NBR-5739:2007 standard [15], using a universal testing machine (AG-X plus, Shimadzu) with a crosshead speed of $3 \mathrm{~mm} / \mathrm{min}$. The data obtained were treated using a software (Trapezium $\mathrm{X}$ v.1.2.6, Shimadzu). A total of 8 specimens for each corrosion condition studied were tested. Fragments of the tested specimens were collected and submitted to a morphological analysis using a scanning electron microscope (SEM, TM 300, Hitachi) coupled with an energy dispersive spectrometer (EDS, X-Flash SVE, Bruker). The physical properties, such as density and porosity, were determined following the BS EN ISO 10545-3 standard [16], using 5 specimens for each condition. Furthermore, the specific weight loss, which is the mass variation per surface area of specimens submitted to the corrosion attack, was determined by:

$$
\mathrm{N}=\frac{\frac{\mathrm{m}_{\mathrm{o}}-\mathrm{m}_{\mathrm{f}}}{\mathrm{m}_{\mathrm{o}}}}{\mathrm{A}_{\mathrm{o}}} \cdot 100
$$

where: $\mathrm{N}$ : specific weight loss $\left(\mathrm{g} / \mathrm{cm}^{2}\right), \mathrm{m}_{\mathrm{o}}$ : initial mass before immersion in acid solution $(\mathrm{g}), \mathrm{m}_{\mathrm{f}}$ : final mass after immersion in acid solution $(\mathrm{g}), \mathrm{A}_{\mathrm{o}}$ : specimen surface $\left(2 \pi r^{2}+2 \pi r h\right.$ for cylindrical specimens, $\left.\mathrm{cm}^{2}\right)$.

\section{RESULTS AND DISCUSSION}

\section{Characterization of fly ash}

Chemical composition: the composition of the fly ash, determined by XRF, considering metal oxides, as well as the $\mathrm{SiO}_{2} / \mathrm{Al}_{2} \mathrm{O}_{3}$ ratio, are listed in Table I. The fly ash used in this study was composed primarily of $\mathrm{SiO}_{2}$ and $\mathrm{Al}_{2} \mathrm{O}_{3}$ with $\mathrm{Fe}_{2} \mathrm{O}_{3}$ as the main components, besides other oxides in smaller quantities. This fly ash was classified as type $\mathrm{F}$ for presenting an amount higher than $70 \%$ of the major oxides $\mathrm{SiO}_{2}+\mathrm{Al}_{2} \mathrm{O}_{3}+\mathrm{Fe}_{2} \mathrm{O}_{3}[12,17]$. The study of the chemical composition of the starting material (fly ash) is of great importance due to the impact it can cause on the final characteristics of the product. The base monomers of formation of the geopolymers can be subdivided into 3 classes: poly(sialate), poly(sialate-siloxo), and poly(sialate-disiloxo), each having a $\mathrm{Si} / \mathrm{Al}$ ratio of $1: 1$, $2: 1$, and $3: 1$, respectively [18]. This proportion is a factor that directly influences the physical and mechanical properties of the material since there is an increase in the repetition of the -Si-O-Al-O- network throughout its structure. Towards the chemical composition of the

Table I - Composition of fly ash used to produce geopolymers (wt $\%$ ).

[Tabela I - Composição da cinza volante utilizada na produção de geopolímeros.]

\begin{tabular}{cccccc}
\hline $\mathrm{SiO}_{2}$ & $\mathrm{Al}_{2} \mathrm{O}_{3}$ & $\mathrm{Fe}_{2} \mathrm{O}_{3}$ & $\mathrm{CaO}$ & Other oxides* & $\mathrm{SiO}_{2} / \mathrm{Al}_{2} \mathrm{O}_{3}^{*}$ \\
\hline 64.88 & 31.23 & 3.88 & 2.99 & 0.35 & 2.07 \\
\hline$* \mathrm{ZnO}, \mathrm{MnO}, \mathrm{Cr}_{2} \mathrm{O}_{3}, \mathrm{SrO}, \mathrm{CuO}, \mathrm{Rb}_{2} \mathrm{O}, \mathrm{Y}_{2} \mathrm{O}_{3}, \mathrm{PbO}, \mathrm{Ga}_{2} \mathrm{O}_{3}, \mathrm{GeO}{ }_{2}, \mathrm{NiO}$, and $\mathrm{NbO} ;{ }^{*}$ molar ratio. & &
\end{tabular}




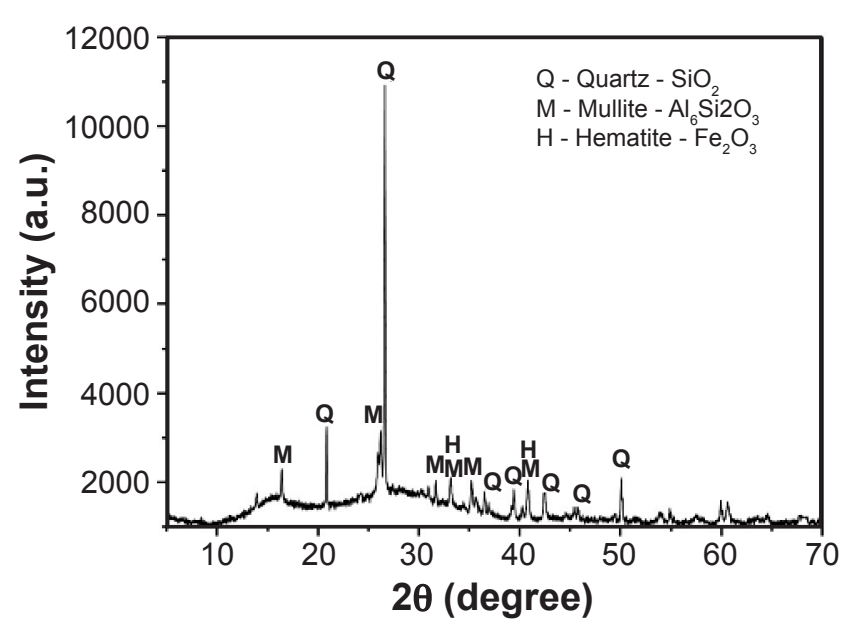

Figure 1: X-ray diffractogram of the fly ash used for geopolimerization.

[Figura 1: Difratograma de raios $X$ da cinza volante utilizada para geopolimerização.]

starting material (Table I), it is possible to report that the geopolymeric products will have characteristics of the poly(sialate-siloxo) (-Si-O-Al-O-Si-O-) base monomer, since $\mathrm{SiO}_{2} / \mathrm{Al}_{2} \mathrm{O}_{3}$ molar ratio found in the fly ash was 2.07 , and a ratio of 2:1 ( $\mathrm{Si} / \mathrm{Al})$ was thus evaluated.

Analysis of crystalline phases: the X-ray diffractogram of the fly ash is shown in Fig. 1. Although this material is known to contain a high concentration of amorphous or semi-crystalline material, diffraction peaks corresponding to the crystalline phases of quartz $\left(\mathrm{SiO}_{2}\right)$, mullite $\left(\mathrm{Al}_{6} \mathrm{Si}_{2} \mathrm{O}_{3}\right)$, and hematite $\left(\mathrm{Fe}_{2} \mathrm{O}_{3}\right)$ were identified [19]. These phases were formed during the burning of mineral coal at high temperatures (1200-1600 ${ }^{\circ} \mathrm{C}$ ) in a highly oxidizing environment [4, 20]. Furthermore, the halo between $10^{\circ}$ and $40^{\circ}(2 \theta)$ in the diffractogram indicated the presence of amorphous material. For the most part, these amorphous aluminosilicates react during the activation of the ash with the alkaline solutions.

Analysis of morphology and surface chemical composition: Fig. 2 presents SEM images of the fly ash particles. The fly ash consisted of spherical particles of varying diameters and random sized ball clusters spread over one another. A study [21] demonstrated that these
Table II - EDS results of fly ash and quantification of the elements of the delimited area.

[Tabela II - Resultados de EDS das cinzas volantes e quantificação dos elementos da área delimitada.]

\begin{tabular}{ccc}
\hline Element & Fraction (wt\%) & Fraction (at\%) \\
\hline Oxygen & 52.68 & 66.94 \\
Silicon & 27.63 & 20.00 \\
Aluminum & 14.11 & 10.63 \\
Iron & 2.97 & 1.08 \\
Potassium & 2.60 & 1.35 \\
Total & 100 & 100 \\
\hline
\end{tabular}

Table III - Oxide contents (wt\%) present in the fly ash used for geopolymer production, obtained by EDS analysis.

[Tabela III - Frações de óxidos (\% em massa) presentes na cinza volante utilizada na produção do geopolímero obtidas por EDS].

\begin{tabular}{ccc}
\hline $\mathrm{SiO}_{2}$ & $\mathrm{Al}_{2} \mathrm{O}_{3}$ & $\mathrm{Fe}_{2} \mathrm{O}_{3}$ \\
\hline 64.41 & 26.61 & 8.98 \\
\hline
\end{tabular}

spheres may be hollow (cenospheres) or may contain other spheres of inferior diameter allocated in their interior (plerospheres). The EDS technique, coupled to SEM, allowed quantitative evaluation of the main chemical elements present in the fly ash. Using the Quantax 70 program, a certain area of the sample was selected, and the main chemical elements present in this region were quantified, as shown in Fig. 2a and Table II, respectively. A new analysis by EDS considering that the metals present were in the form of their most stable oxides $\left(\mathrm{SiO}_{2}, \mathrm{Al}_{2} \mathrm{O}_{3}, \mathrm{Fe}_{2} \mathrm{O}_{3}\right)$ was realized, where it was possible to observe that the chemical composition presented by this technique was close to that found by XRF analysis, presenting higher concentrations of silica and alumina (Table III). The studies of the chemical composition of the fly ash allowed to classify it as type $\mathrm{F}$, given that the fly ash had a $\mathrm{SiO}_{2}, \mathrm{Al}_{2} \mathrm{O}_{3}$, and $\mathrm{Fe}_{2} \mathrm{O}_{3}$ content higher than $70 \%$, while type $\mathrm{C}$ is close to $50 \%$ and have large amounts of Ca element [12].
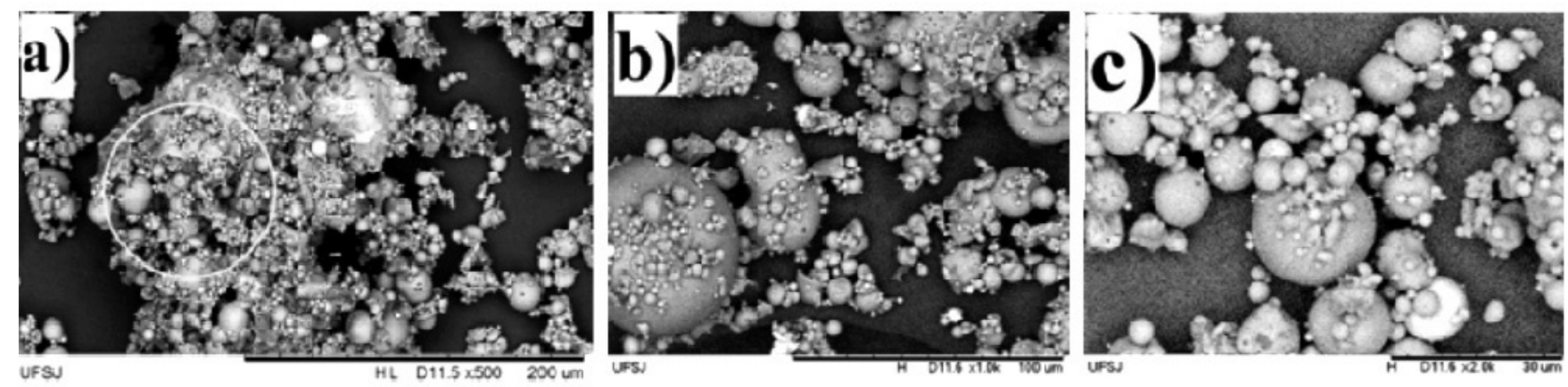

Figure 2: SEM micrographs of the as-received fly ash at different magnifications.

[Figura 2: Micrografias obtidas por microscopia eletrônica de varredura da cinza volante em diferentes aumentos.] 
Characterization of the geopolymers before and after corrosion in acid solutions

Compressive strength and modulus of elasticity: the variations of compressive strength of the geopolymer subjected to corrosion attacks in $\mathrm{H}_{2} \mathrm{SO}_{4}$ and $\mathrm{HCl}$ acid solutions with concentrations of 3,6 , and 9 vol\% after immersion for $0,1,3,7,14$, and 28 days are shown in Figs. $3 \mathrm{a}$ and $3 \mathrm{~b}$. The geopolymers produced by the alkaline activation of fly ash with a $16 \mathrm{~mol} / \mathrm{L} \mathrm{NaOH}$ solution achieved a compressive strength of about $42 \mathrm{MPa}$ after 1 day of curing. The strength increased to more than $50 \mathrm{MPa}$ after 3 days, showing a decrease of strength for longer curing periods, until a final strength of about $40 \mathrm{MPa}$ after 28 days. The strength reduction after 3 days may be associated with the excess of $\mathrm{OH}^{-}$ions from the $\mathrm{NaOH}$ solution, which, over time, promoted deterioration of the NASH gel structure (where $\mathrm{N}=\mathrm{Na}_{2} \mathrm{O}, \mathrm{A}=\mathrm{Al}_{2} \mathrm{O}_{3}, \mathrm{~S}=\mathrm{SiO}_{2}, \mathrm{H}=\mathrm{H}_{2} \mathrm{O}$ ) responsible for the mechanical resistance. This excess of $\mathrm{OH}^{-}$ions in the system caused precipitation of aluminosilicates, promoting deterioration of the polymer chains and diminishing the mechanical resistance of the material [22]. As demonstrated in [23], a high concentration of excess alkali can result in the supersaturation of $\mathrm{Na}_{2} \mathrm{O}$, leading to a deterioration of the material.

The variation of compressive strength after immersion in sulfuric acid solutions is shown in Fig. 3a. The strength of the geopolymer samples decreased with increasing concentration of the acid solutions and with increasing time of exposure. It can also be observed that the effect of immersion time was more pronounced than the concentration of the acid solutions. Strength decreased significantly already during the first day of exposure to the $\mathrm{H}_{2} \mathrm{SO}_{4}$ solutions from initially $40 \mathrm{MPa}$ to about 12 and $10 \mathrm{MPa}$ for solutions of $3 \%$ and $9 \%$ $\mathrm{H}_{2} \mathrm{SO}_{4}$, respectively. Longer exposure to the acid solutions of up to 28 days resulted in a further strength reduction to about $8 \mathrm{MPa}$, corresponding to a residual strength of about $20 \%$ of the initial strength. However, the investigated samples maintained their structural integrity during the acid attack and, therefore, these geopolymers may be used as binding materials in environments containing $\mathrm{H}_{2} \mathrm{SO}_{4}$ [24]. The variation of the strength of samples immersed in $\mathrm{HCl}$ solutions is shown in Fig. 3b. It can be observed that the strength also decreased with increasing concentration of
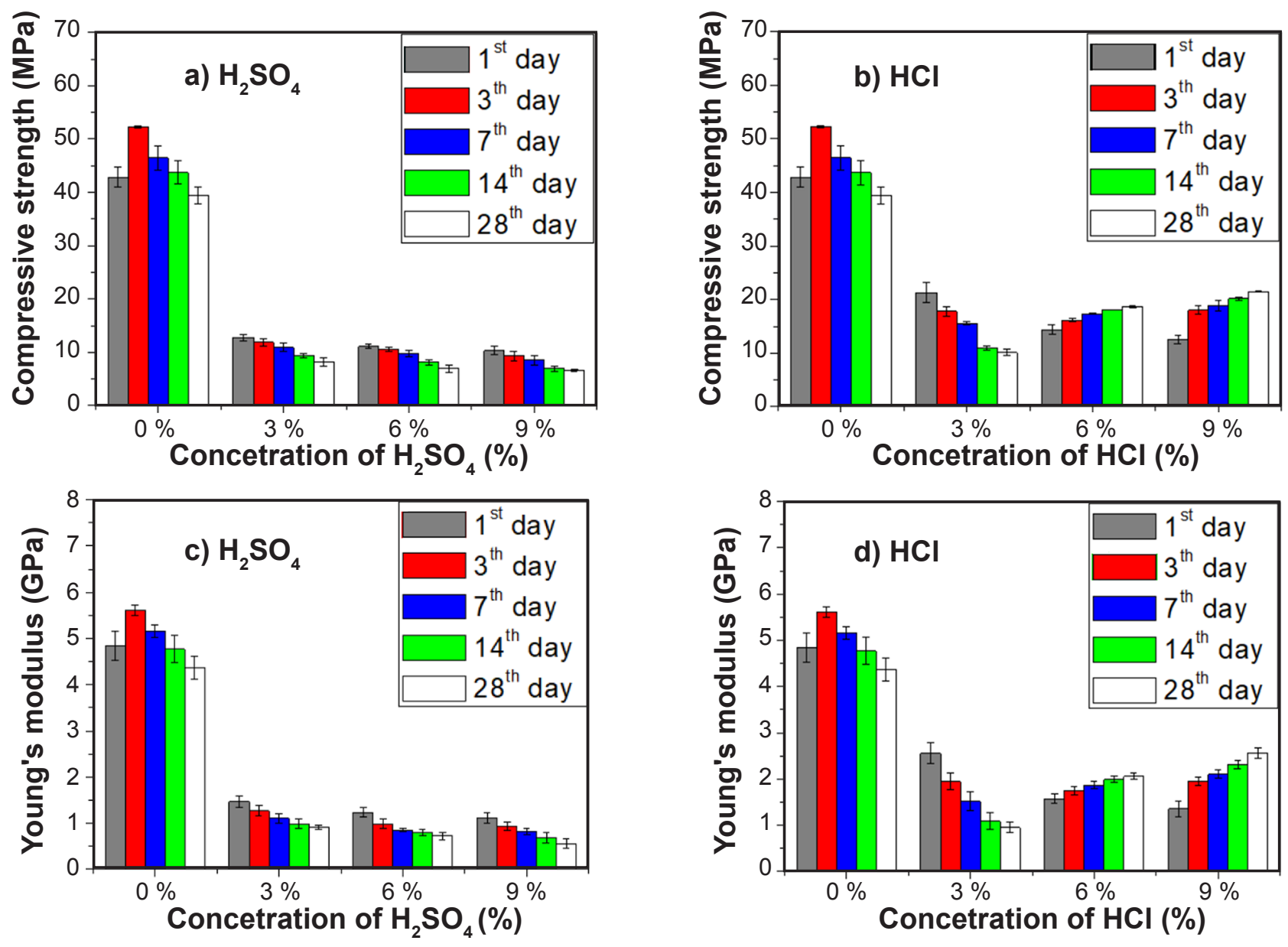

Figure 3: Compressive strength $(a, b)$ and Young's modulus $(c, d)$ of fly ash-based geopolymer immersed in sulfuric acid (a,c) and hydrochloric acid $(b, d)$ with different concentrations and immersion times.

[Figura 3: Resistência à compressão $(a, b)$ e módulo elástico $(c, d)$ de geopolímero à base de cinza volante imerso em ácido sulfúrico (a,c) e ácido clorídrico $(b, d)$ com diferentes concentrações e tempos de imersão.] 
the acid solutions and increasing time of exposure, and the main strength reduction occurred during the first day of immersion. However, strength reduction in $\mathrm{HCl}$ solutions was markedly less pronounced compared to the variation observed for $\mathrm{H}_{2} \mathrm{SO}_{4}$. Strength after 1 day of immersion in $\mathrm{HCl}$ solutions was reduced to approximately 22 and 15
$\mathrm{MPa}$ in solutions with $\mathrm{HCl}$ concentrations of $3 \%$ and $9 \%$, respectively. These results were close to those observed in [10], which reported a $30 \%$ reduction of mechanical resistance. Furthermore, a continuous strength reduction is only observed for samples immersed in $3 \% \mathrm{HCl}$ solution up to 14 days. In other cases, even an increase in strength
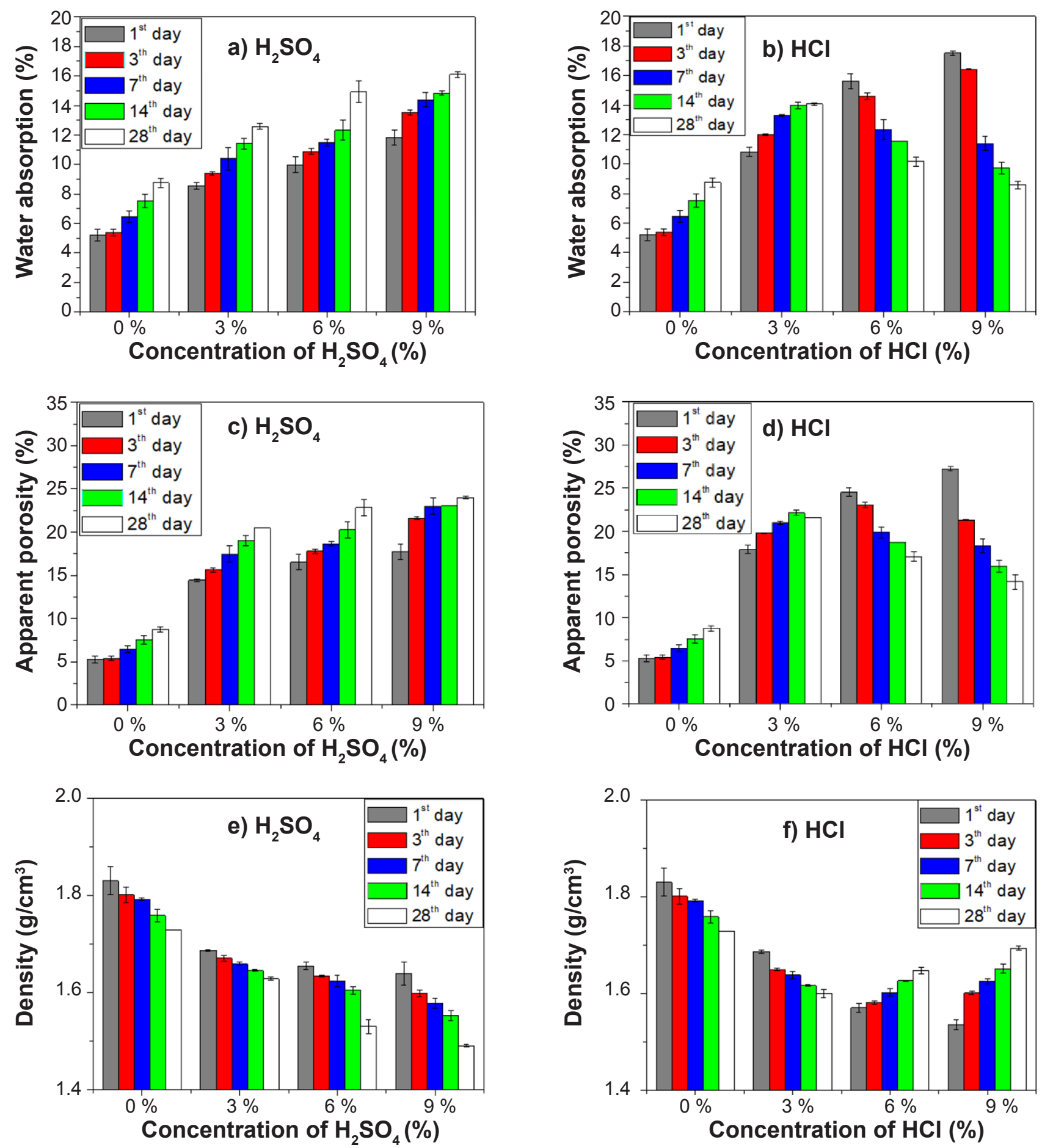

Figure 4: Water absorption (a,b), apparent porosity (c,d), and density (e,f) of fly-ash based geopolymer after corrosion in sulfuric (a,c,e) and hydrochloric $(\mathrm{b}, \mathrm{d}, \mathrm{f})$ acid solutions with different concentrations and immersion times.

[Figura 4: Absorção de água $(a, b)$, porosidade aparente $(c, d)$ e densidade $(e, f)$ de geopolímero à base de cinza volante após corrosão em soluções de ácido sulfúrico $(a, c, e)$ e clorídrico $(b, d, f)$ com diferentes concentrações e tempos de imersão.] 
was observed with increasing time of immersion. This unexpected and contradictory behavior can be explained by the precipitation of $\mathrm{NaCl}$ crystals inside the pores (as verified by SEM and EDS analysis, as shown below), reducing open porosity and therefore hindering the penetration of the acid solution into the bulk of the materials and also resulting in a slight increase in strength. The formation of $\mathrm{NaCl}$ was due to the reaction of $\mathrm{HCl}$ with excess $\mathrm{NaOH}$ used in the activator solution for the geopolimerization process, as presented by:

$$
\left.\begin{array}{l}
\mathrm{HCl} \rightarrow \mathrm{H}^{+}+\mathrm{Cl}^{-} \\
\mathrm{NaOH} \rightarrow \mathrm{Na}^{+}+\mathrm{OH}^{-}
\end{array}\right\} \mathrm{H}^{+} \mathrm{Cl}^{-} \rightarrow \mathrm{Na}^{+} \mathrm{OH}^{-} \rightarrow \mathrm{NaCl}+\mathrm{H}_{2} \mathrm{O}
$$

The Young's modulus was determined by the stress versus strain curves generated during the compression tests. The results of the variation of the elastic modulus of the geopolymer samples submitted to the corrosion tests are shown in Figs. $3 \mathrm{c}$ and $3 \mathrm{~d}$. Similar behavior as observed for the compressive strength was verified, that is, as the acid concentration and the immersion time increased, the elastic modulus decreased. The observed reduction in Young's modulus was more pronounced for the attack of sulfuric acid than hydrochloric acid. Furthermore, the formation of $\mathrm{NaCl}$ crystals reflected also in the variation of the elastic modulus, which increased slightly for higher concentrated solutions, $6 \%$ and $9 \% \mathrm{HCl}$, and for longer periods, after 7 days, due to the reduced porosity.

Analysis of physical properties (water absorption, apparent porosity, and density): these physical properties were measured following the BS EN ISO 10545-3:1997 standard (Fig. 4). It was possible to evaluate that immersion in $\mathrm{H}_{2} \mathrm{SO}_{4}$ resulted in an increase in porosity (Fig. 4c) and, consequently, to higher water absorption (Fig. 4a) with increasing concentration and immersion time. The mean density (Fig. 4e) showed a reduction of behavior when the concentration and the immersion time increased; it was directly connected to the porosity increase as quoted. Samples immersed in $\mathrm{HCl}$ exhibited a different behavior in comparison to $\mathrm{H}_{2} \mathrm{SO}_{4}$. With increasing concentration of the $\mathrm{HCl}$ solutions and time of immersion, a reduction of porosity and water absorption was observed, besides an increase in the density. As already described, these variations were attributed to the formation of $\mathrm{NaCl}$ crystals in the pores of the geopolymers. In particular, it was possible to evaluate the behavior of specimens that did not undergo any corrosion process (indicated by $0 \%$ ). From the $1^{\text {st }}$ to the $28^{\text {th }}$ day, it was possible to observe an increase in the pore percentage (Figs. $4 \mathrm{c}$ and $4 \mathrm{~d}$ ) and, similarly, an increase in water absorption (Figs. 4a and $4 b$ ). This fact may be related to the high concentration of $\mathrm{OH}^{-}$ions from the high concentration of activating solution $(\mathrm{NaOH} 16 \mathrm{~mol} / \mathrm{L})$, which tended to deteriorate the structure and, consequently, promoted the decrease of the durability of the geopolymer. This can be related to the possible pore and microcracking formations after acid contact.

Mass variation: Fig. 5 shows the normalized mass change (variation of mass per surface area) of samples after corrosion in $\mathrm{HCl}$ and $\mathrm{H}_{2} \mathrm{SO}_{4}$ solutions with different concentrations and for different periods of exposure. As can be seen from Fig. 5a, the mass of the samples decreased with increasing concentration of $\mathrm{HCl}$ solutions for each exposure period and also decreased considering for longer immersion times. This observation reflected two opposing phenomena: first, the mass loss by the acid attack, which increased with increasing acid concentration and, secondly, the precipitation of $\mathrm{NaCl}$ inside the pores, which resulted in a decreasing mass loss with increasing exposure time. On the contrary, samples exposed to $\mathrm{H}_{2} \mathrm{SO}_{4}$ acid solutions showed increasing mass loss for both variables, increasing acid concentration and exposure time, as shown in Fig. $5 b$.

Table IV shows the mass variation of the samples attacked by respective acids and concentrations after the $1^{\text {st }}$ and $28^{\text {th }}$ days of immersion. Samples immersed in $\mathrm{HCl}$ solutions revealed a weight loss ranging between 11.5 and $15.2 \mathrm{wt} \%$ after 1 day, depending on the acid concentration. However, this weight loss was reduced after 28 days of immersion between 1.9 and 6.5 $\mathrm{wt} \%$ due to the formation of $\mathrm{NaCl}$ crystals precipitated in the pores of the geopolymer material, as already discussed. Samples
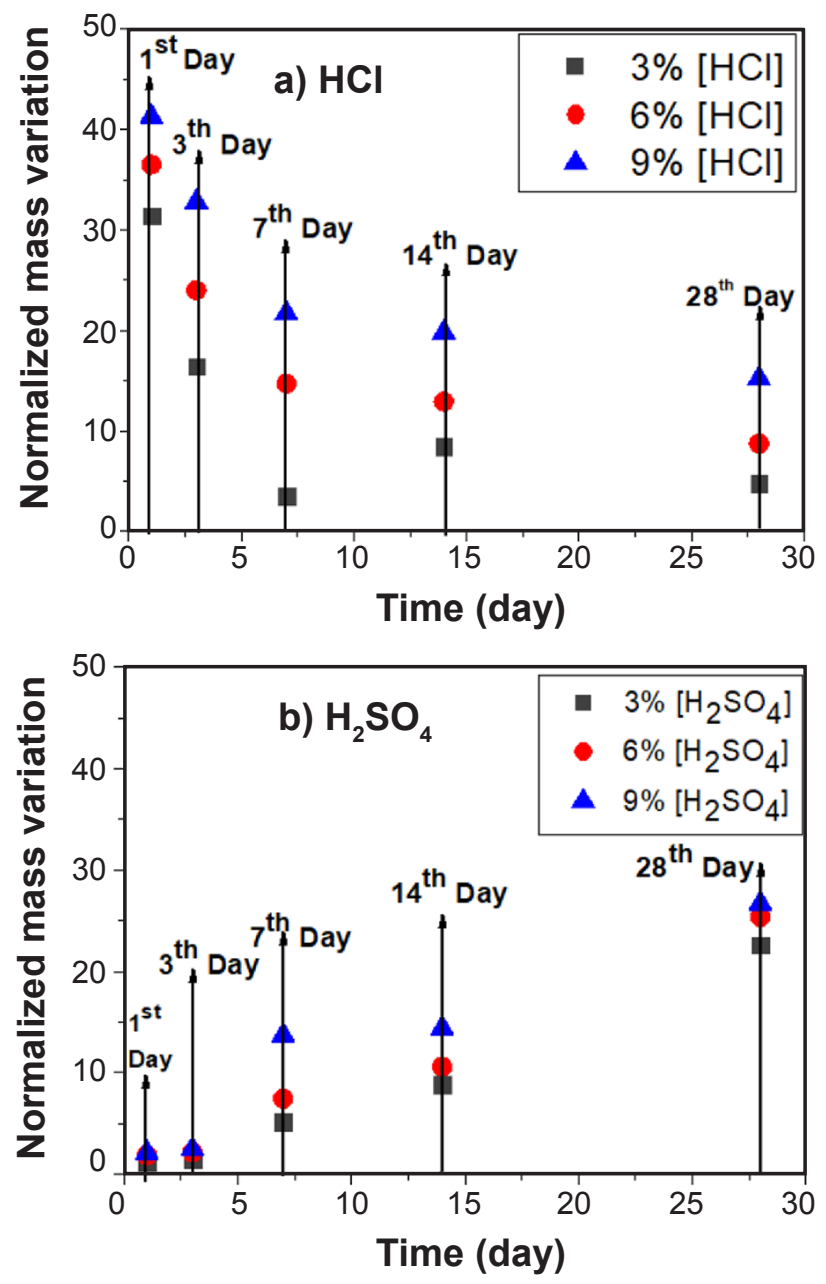

Figure 5: Normalized mass variation of samples after corrosion in hydrochloric (a) and sulfuric (b) acid solutions with different concentrations and immersion times.

[Figura 5: Variação de massa normalizada de amostras após corrosão em soluções de ácido clorídrico (a) e sulfúrico (b) com diferentes concentrações e tempos de imersão.] 
Table IV - Mean percentage differences in the mass of samples immersed in 3\%, 6\%, and $9 \%(\mathrm{v} / \mathrm{v})$ of $\mathrm{HCl}$ or $\mathrm{H}_{2} \mathrm{SO}_{4}$ for the $1^{\text {st }}$ and $28^{\text {th }}$ days.

[Tabela IV - Diferenças percentuais médias da massa das amostras imersas em 3\%, 6\% e 9\% (v/v) de $\mathrm{HCl}$ ou $\mathrm{H}_{2} \mathrm{SO}_{4}$ no $1^{\circ}$ e $28^{\circ}$ dias].

\begin{tabular}{ccc}
\hline \multirow{2}{*}{ Sample } & \multicolumn{2}{c}{ Mass variation $(\%)$} \\
& $1^{\text {st }}$ day & $28^{\text {th }}$ day \\
\hline $\mathrm{HCl} 3 \%$ & 11.5 & 1.9 \\
$\mathrm{HCl} 6 \%$ & 13.7 & 8.0 \\
$\mathrm{HCl} 9 \%$ & 15.2 & 6.5 \\
$\mathrm{H}_{2} \mathrm{SO}_{4} 3 \%$ & 4.6 & 9.1 \\
$\mathrm{H}_{2} \mathrm{SO}_{4} 6 \%$ & 7.0 & 10.3 \\
$\mathrm{H}_{2} \mathrm{SO}_{4} 9 \%$ & 8.0 & 10.8 \\
\hline
\end{tabular}

exposed to $\mathrm{H}_{2} \mathrm{SO}_{4}$ acid solutions exhibited significantly lower weight losses after 1 day of immersion, varying from 4.6 to 8.0 $\mathrm{wt} \%$ for solutions of $3 \%$ and $9 \% \mathrm{H}_{2} \mathrm{SO}_{4}$, respectively. During further exposure of up to 28 days, the weight change increased continuously, resulting in the final weight losses between 9.1 and $10.8 \mathrm{wt} \%$. Comparing both acid solutions, it can be stated that the main detrimental effects already took place after 1 day of exposure and that the attack by $\mathrm{HCl}$ was more severe than $\mathrm{H}_{2} \mathrm{SO}_{4}$. However, due to the formation of $\mathrm{NaCl}$ inside the pores of samples exposed to $\mathrm{HCl}$ solutions, this trend was inverted for longer exposure periods.

Morphology and surface chemical composition: the microstructural changes of samples during the attack by $\mathrm{HCl}$ solutions were evaluated by scanning electron microscopy, as shown in Fig. 6, for original samples and samples immersed in solutions of $3 \%, 6 \%$, and $9 \% \mathrm{HCl}$ for 1 and 28 days. Comparing the surfaces of samples
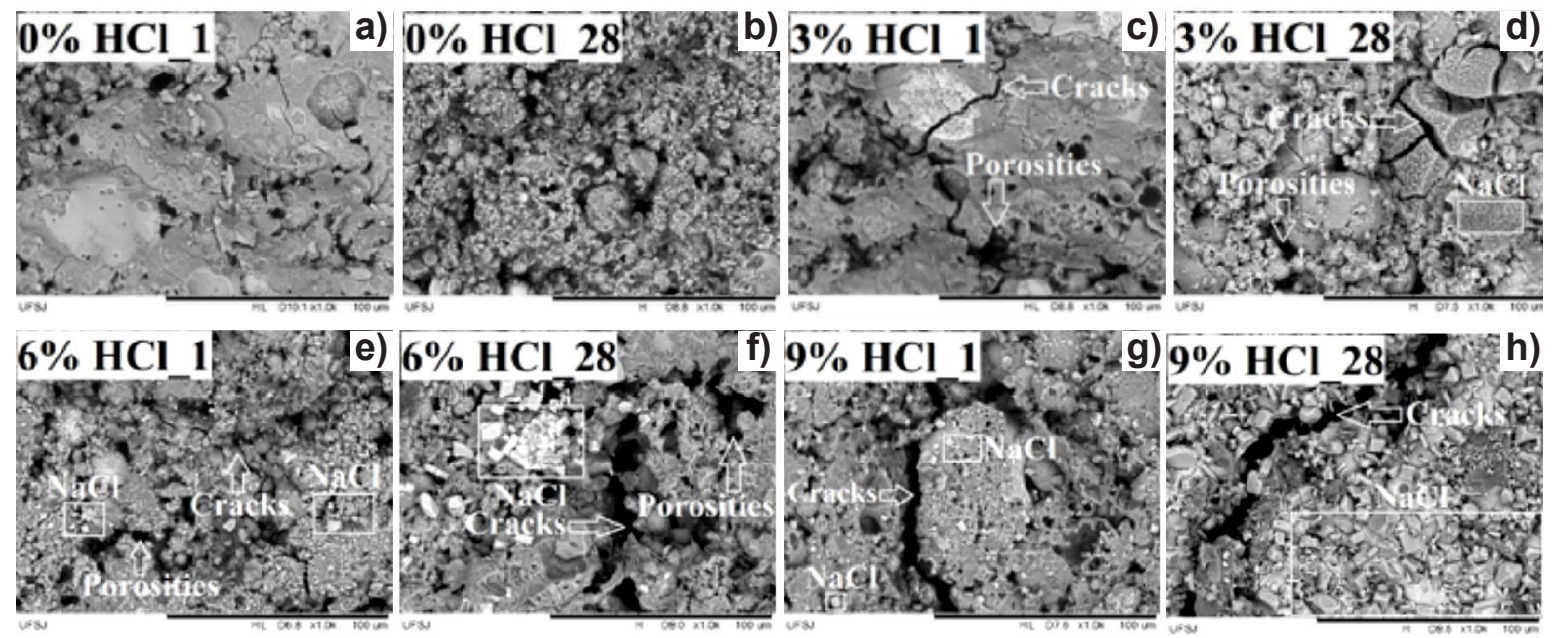

Figure 6: SEM micrographs of original samples (a,b) and samples immersed in solutions of 3\% (c,d), 6\% (e,f), and 9\% (g,h) $\mathrm{HCl}$ solutions for 1 day (a,c,e,g) and 28 days (b,d,f,h).

[Figura 6: Micrografias obtidas por microscopia eletrônica de varredura de amostras originais (a,b) e amostras imersas em soluções de $3 \%(c, d), 6 \%(e, f)$ e $9 \%(g, h)$ de $\mathrm{HCl}$ por 1 dia $(a, c, e, g)$ e 28 dias $(b, d, f, h)$.]

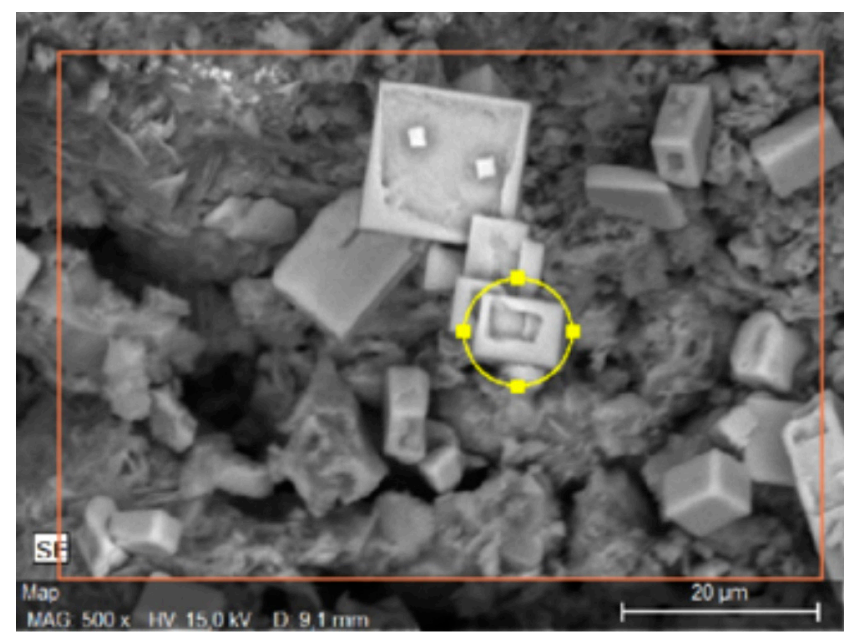

Figure 7: Crystals precipitated in the geopolymer structure after exposure to the $\mathrm{HCl}$ solution.

[Figure 7: Precipitação dos cristais na estrutura do geopolímero após exposição em solução de $\mathrm{HCl}$.]

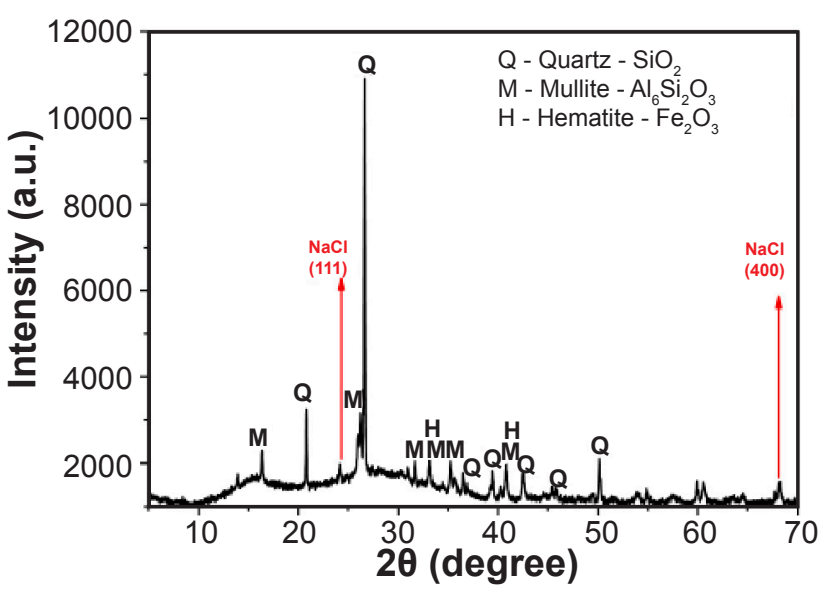

Figure 8: XRD pattern of a geopolymer sample after exposure to a $9 \% \mathrm{HCl}$ solution for 28 days.

[Figure 8: Difratograma de raios $X$ de amostra de geopolímero após exposição à solução $9 \%$ de $\mathrm{HCl}$ por 28 dias.] 
Table V - EDS results (at\%) of the crystals formed in the geopolymer microstructure.

[Tabela V - Resultados de EDS (\% atômica) dos cristais formados na microestrutura do geopolímero.]

\begin{tabular}{ccc}
\hline Sodium & Chlorine & Total \\
\hline 53.83 & 46.17 & 100 \\
\hline
\end{tabular}

that did not undergo acid immersion with those that were immersed in the $\mathrm{HCl}$ solutions, it was possible to observe that the corrosion attack resulted in increasing porosity and cracks with increasing acid concentration and exposure time. Furthermore, the formation of crystals in samples exposed for longer periods was also observed in increasing amounts for increasing acid concentration. A detailed microscopical analysis of these crystals (Fig. 7) revealed its rectangular shape, and it was identified by EDS analysis (Table $\mathrm{V}$ ) as $\mathrm{NaCl}$ crystals, as shown by a $\mathrm{Na} / \mathrm{Cl}$ ratio of 1.16 , close to 1 as for the stoichiometric $\mathrm{NaCl}$ compound. The identity of the crystals has also been confirmed by XRD analysis (Fig. 8), as indicated by diffraction peaks corresponding to the (111) and (400) planes of $\mathrm{NaCl}$. These $\mathrm{NaCl}$ crystals, as mentioned, was formed by the reaction of $\mathrm{Na}^{+}$ions from the $\mathrm{NaOH}$ alkaline activator with $\mathrm{Cl}^{-}$ions from the $\mathrm{HCl}$ solutions. The formation of these crystals inside the pores of the geopolymer structure was the reason for the measured decrease of porosity by absorption and, simultaneously, the increase of the mechanical resistance of this material.

The microstructural changes in the geopolymer samples caused by $\mathrm{H}_{2} \mathrm{SO}_{4}$ solutions are shown in Fig. 9 for the original samples and samples immersed in solutions of $3 \%, 6 \%$, and $9 \% \mathrm{H}_{2} \mathrm{SO}_{4}$ for 1 and 28 days. The SEM images of the corroded sample clearly showed increasing porosity and crack formation with increasing concentration of the acid solutions and with increasing time of exposure, agreeing with the results of density, water absorption, and mechanical resistance.

\section{CONCLUSIONS}

The fly ash used in this study was composed of $\mathrm{SiO}_{2}$, $\mathrm{Al}_{2} \mathrm{O}_{3}$, and $\mathrm{Fe}_{2} \mathrm{O}_{3}$ as major species. Therefore, this fly ash was classified as type $\mathrm{F}$ with a $\mathrm{SiO}_{2} / \mathrm{Al}_{2} \mathrm{O}_{3}$ molar ratio of 2.07 . The geopolymer produced by alkaline activation of the fly ash with a $16 \mathrm{~mol} / \mathrm{L} \mathrm{NaOH}$ solution had a compressive strength of about $42 \mathrm{MPa}$ after 1 day of curing, increasing to more than $50 \mathrm{MPa}$ after 3 days. However, strength decreased for longer curing periods until a final strength of about $40 \mathrm{MPa}$ after 28 days, probably associated with excess $\mathrm{OH}^{-}$ions from the $\mathrm{NaOH}$ solution that, over time, promoted deterioration of the NASH gel structure $\left(\mathrm{N}=\mathrm{Na}_{2} \mathrm{O}\right.$, $\mathrm{A}=\mathrm{Al}_{2} \mathrm{O}_{3}, \mathrm{~S}=\mathrm{SiO}_{2}, \mathrm{H}=\mathrm{H}_{2} \mathrm{O}$ ). The compressive strength of the geopolymer samples decreased with increasing concentration of the acid solutions and with increasing time of exposure. It was observed that the effect of immersion time was more pronounced than the concentration of the acid solutions. Strength decreased significantly during the first day of exposure for both acid solutions; in the case of $\mathrm{H}_{2} \mathrm{SO}_{4}$, from initially $40 \mathrm{MPa}$ to about 12 and $10 \mathrm{MPa}$ for $3 \%$ and $9 \%$ acid solutions, respectively. The strength reduction after $\mathrm{HCl}$ solution immersion was markedly less pronounced compared to the variation observed for $\mathrm{H}_{2} \mathrm{SO}_{4}$. Strength after 1 day of immersion in $\mathrm{HCl}$ solutions was reduced to approximately 22 and $15 \mathrm{MPa}$ in 3\% and 9\% $\mathrm{HCl}$ solutions, respectively. The observed strength variation was consistent with the variations in density, porosity, and weight change of the samples. However, for longer exposure periods of up to 28 days, significantly different behavior of the strength of the geopolymer samples immersed in $\mathrm{HCl}$ or $\mathrm{H}_{2} \mathrm{SO}_{4}$ solutions was observed. While the strength of samples immersed in $\mathrm{H}_{2} \mathrm{SO}_{4}$ solutions continued to be slightly reduced, the strength of samples immersed in $\mathrm{HCl}$ solutions even increased. This behavior was attributed to the formation of $\mathrm{NaCl}$ crystals in pores, as confirmed by scanning electron microscopy and $\mathrm{X}$-ray diffraction analysis. Under all conditions studied, the
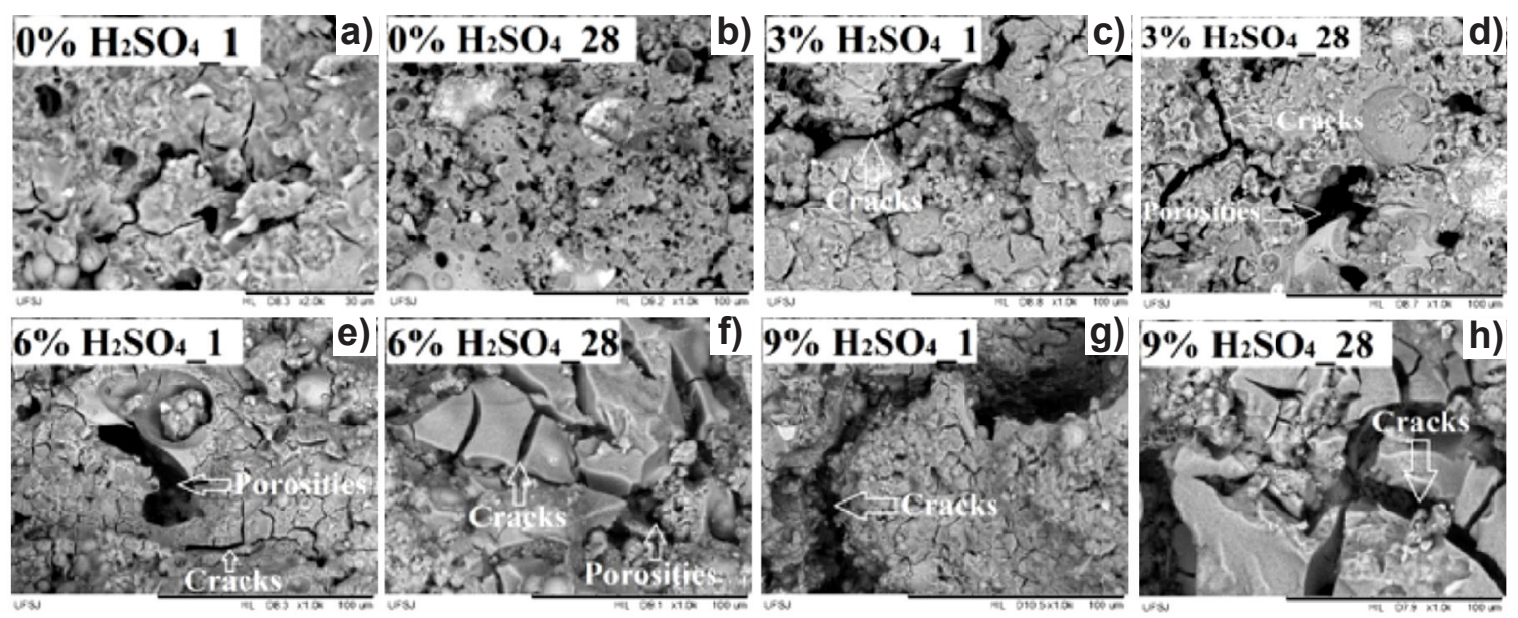

Figure 9: SEM micrographs of original samples (a,b) and samples immersed in solutions of 3\% (c,d), 6\% (e,f), and 9\% $(\mathrm{g}, \mathrm{h}) \mathrm{H}_{2} \mathrm{SO}_{4}$ solutions for 1 day $(\mathrm{a}, \mathrm{c}, \mathrm{e}, \mathrm{g})$ and 28 days $(\mathrm{b}, \mathrm{d}, \mathrm{f}, \mathrm{h})$.

[Figura 9: Micrografias obtidas por microscopia eletrônica de varredura de amostras originais (a,b) e amostras imersas em soluções de $3 \%(c, d), 6 \%(e, f)$ e $9 \%(g, h)$ de $\mathrm{H}_{2} \mathrm{SO}_{4}$ por 1 dia $(a, c, e, g)$ e 28 dias $(b, d, f, h)$.] 
investigated samples maintained their structural integrity after the acid attack and, therefore, this geopolymer material may be viable for the use as binding materials exposed to acid environments.

\section{ACKNOWLEDGMENT}

This work was developed with the support of the financing agency, CAPES: Coordenação de Aperfeiçoamento de Pessoal de Nível Superior.

\section{REFERENCES}

[1] A. Ali, J. Thomas, N.B. Parappattu, Int. J. Innov. Res. Adv. Eng. 3 (2016) 20.

[2] SNIC, "Relatório anual", Sind. Nac. Ind. Cimento (2013).

[3] J. Davidovits, C. James, $2^{\text {nd }}$ Int. Conf. Geopolymer, Geopolymer Inst., Saint-Quentin (1999).

[4] J.L. Provis, S.J.V. Deventer (Eds.), "Geopolymers: structures, processing, properties and industrial applications", CRC Press, New York (2009).

[5] J.L. Provis, S.A. Bernal, Annu. Rev. Mater. Res. 44 (2014) 299.

[6] P. Duxson, A. Fernandez-Jiménez, J.L. Provis, G.C. Luckey, P. Angel, S.J.V. Deventer, J. Mater. Sci. 42 (2006) 2917.

[7] J. Davidovits, Geopolymer' 88, $1^{\text {st }}$ Eur. Conf. Soft Mineral., Geopolymer Inst., Compiègne 1 (1988) 25.

[8] K.T. Nguyen, Y.H. Lee, J. Lee, N. Ahn, J. Asian Archit. Build. Eng. 12 (2013) 317.

[9] T. Bakharev, Cem. Concr. Res. 35 (2005) 658.

[10] J. Temuujin, A. Minjigmaa, M. Lee, N.C. Tan, A. van
Riessen, Cem. Concr. Compos. 33 (2011) 1086.

[11] A.M.A. Guerrero, R.A.R. Salazar, R.M. Gutiérrez, Appl. Clay Sci. 135 (2017) 437.

[12] ASTM C618, "Standard specification for coal fly ash and raw or calcined natural pozzolan for use as a mineral admixture in concrete", Am. Soc. Test. Mater., USA (2010). [13] NBR 5738, "Concreto: procedimento para moldagem e cura de corpos de prova", ABNT, Brazil (2015).

[14] ASTM C267-01, "Standard test methods for chemical resistance of mortars, grouts, and monolithic surfacings and polymer concretes”, Am. Soc. Test. Mater., USA (2012).

[15] NBR 5739, "Concreto: ensaio de compressão de corposde-prova cilíndricos", ABNT, Brazil (2007).

[16] BS EN ISO 10545-3, "Ceramic tiles, part 3: determination of water absorption, apparent porosity, apparent relative density and bulk density", Int. Org. Stand., Geneva (1997).

[17] M. Thomas, "Optimizing the use of fly ash in concrete", Portland Cem. Ass., New Jersey (2007).

[18] A. Fernández-Jiménez, A. Palomo, M. Criado, Cem. Concr. Res. 35, 6 (2005) 1204.

[19] R.P. Williams, A.V. Riessen, Fuel, 89 (2010) 3683.

[20] A.G.S. Azevedo, K. Strecker, A.G. Araújo, C.A. Silva, Cerâmica 63, 366 (2017) 143.

[21] X. Guo, H. Shi, W.A. Dick, Cem. Concr. Compos. 32 (2010) 142.

[22] A.G.S. Azevedo, K. Strecker, Ceram. Int. 43 (2017) 9012.

[23] P. Mazur, J. Mikula, J.S. Kowalski, Adv. Sci. Technol. 7 (2013) 88.

[24] X.T. Song, M. Marosszeky, M. Brungs, Z.T, Chang, $10^{\text {th }}$ Int. Conf. Durabil. Build. Mater. Compon., School Civil Environ. Eng., France (2005) 7.

(Rec. 18/01/2020, Rev. 13/05/2020, Ac. 16/05/2020) 